\title{
Aberrant Hypermethylation of APC Tumor Supressor Gene in Acute Leukemia Patients
}

\author{
Ozden HATIRNAZ NG ${ }^{1}$, Sinem FIRTINA ${ }^{1}$, Yucel ERBILGIN ${ }^{1}$, Ugur OZBEK $^{2}$, Muge SAYITOGLU ${ }^{1}$ \\ ${ }^{1}$ Istanbul University, Aziz Sancar Institution for Experimental Medical Research, Department of Genetics \\ ${ }^{2}$ Acıbadem University, Acıbadem Faculty of Medicine, Department of Medical Genetics, Istanbul, TURKEY
}

\begin{abstract}
Wingless Type (WNT) signaling pathway is an evolutionarily conserved pathway that is crucial for the cell fate determination, survival and expansion of lymphocyte progenitors. It has been demonstrated that deregulated WNT signaling is one of the participating mechanism underlying lymphoid leukemogenesis. Inactivating mutations and methylation in Adenomatous Polyposis Coli (APC) gene, a negative regulator of WNT pathway, can cause ligand independent WNT pathway simulation. In this study, promoter methylation and expression of the APC gene is evaluated in childhood lymphoid and myeloid acute leukemia patients $(\mathrm{n}=118)$ and representative cell lines by using methylation specific PCR (MS-PCR) and real time quantitative PCR (QRT-PCR). APC gene promoter found hypermethylated in the $56 \%$ of childhood acute leukemia patients [49.2\% of B-cell acute lymphoblastic leukemia (B-ALL), $62.5 \%$ of T-cell acute lymphoblastic leukemia (T-ALL) and $64.1 \%$ of Acute myeloid leukemia (AML)]. To evaluate the reflection of promoter methylation, APC mRNA levels were examined and found that all acute lymphoblastic leukemia subgroups have statistically lower $A P C$ expression levels compared to controls. Although there was no association with clinical parameters, promoter hypermethylation of $A P C$ gene seems to be a common epigenetic event in acute leukemia and leading to differential expression levels among different acute leukemia phenotypes.
\end{abstract}

Keywords: APC, methylation, Expression, Acute leukemia, WNT signaling

ÖZET

Akut Lösemi Hastalarında APC Tümör Baskılayıcı Geninin Artmış Hipermetilasyonu

WNT sinyal ileti yolağı evrimsel olarak korunmuş, lenfosit progenitor hücrelerin büyümesi ve farklılaşmasında görevli önemli bir yolaktır. Son yıllarda yapılan çalışmalar WNT sinyal ileti yolağının hematopoetik malignansilerde de önemli bir yeri olduğuna işaret etmektedir. WNT sinyal ileti yolağında görev alan APC geni, B-katenini degrede eden degredasyon kompleksi elemanlarından birisi olması nedeniyle yolağın negatif regülasyonunda anahtar role sahiptir. Gende meydana gelen inaktive edici mutasyonlar veya metillenme, WNT aktivasyonuna sebep olmaktadır. Bu çalışmada APC geni ekspresyonu ve metilasyonu çocukluk çağı akut lenfoblastik ve myeloblastik lösemi hastalarında $(n=118)$ metilasyon spesifik PZR ve eş zamanlı kantitatif PZR ile incelenmiştir. APC geni promotör bölgesi hastaların \%56'sında (\%49.2 B-ALL, \%62.5 T-ALL \%64.1 AML hastalarında) hipermetile olarak tespit edilmiştir. Metilasyonun, gen ekspresyonuna olan etkisini değerlendirmek için APC mRNA seviyeleri incelendiğinde tüm akut lenfoblastik lösemi hastalarında anlatımın kontrollere göre istatistiksel olarak azaldığı görülmüştür. $A P C$ anlatımı ile klinik parametreler arasında bir korelasyon gözlememekle birlikte, APC promotör metilasyonunun farklı ALL fenotipleri arasında farklı gen anlatım düzeylerine neden olduğu gözlenmiştir.

Anahtar Kelimeler: APC, metilasyon, Ekspresyon, Akut lösemiler, WNT sinyal ileti yolağı 


\section{INTRODUCTION}

Wingless Type (WNT) pathway is one of the evolutionarily conserved signal transduction pathways that control several stages of development, including proliferation, cell fate, polarity and migration of cells. WNT signals are important for the survival and expansion of lymphocyte progenitors, it has been suggested that deregulated WNT signaling could be one mechanism underlying leukemogenesis. ${ }^{1,2}$

Most of the studies reported that up-regulation of B-CATENIN causes the stimulation of WNT pathway and overexpressed WNT proteins contribute to the pathogenesis of hematologic malignancies like acute myeloid leukemia (AML), chronic lymphocytic leukemia (CLL) and T cell acute lymphoblastic leukemia. ${ }^{3-5}$ APC gene is a multi-domain protein and inactivating mutations or methylations lead to deregulated WNT signaling which has been firstly implicated in colorectal tumor evolution. ${ }^{6,7}$ $A P C$ gene is the negative regulator of the WNT pathway, has been methylated in solid tumors especially colon prostate, breast cancers, multiple myeloma and acute leukemia. ${ }^{8-12}$

In our previous study we examined $A P C$ gene mutations in $\mathrm{T}$ cell and B cell ALL patients and showed that $A P C$ gene mutations are not a common mechanism for acute leukemia. ${ }^{13}$ Methylation in the promoter region is a frequent, acquired epi- genetic event involved in the pathogenesis of different type of human malignancies including leukemia. The purpose of this study was to determine the role of promoter hypermethylation of the APC gene in different acute leukemia subgroups and its association with clinic representation.

\section{MATERIALS AND METHODS}

\section{Patients and Controls}

A total of 118 acute leukemia patients (B-ALL $\mathrm{n}=$ 63, T-ALL $n=16$, total AML $n=39$ ) who were diagnosed at Istanbul and Cerrahpasa Medical Faculties of Istanbul University were included in this study. In our cohort, 71 patients were childhood ALL and eight patients were adult ALL. Median WBC was $42300 \mathrm{mcL}$. Four patients were positive for $\mathrm{t}(12 ; 21)$, three patients were positive for $\mathrm{t}(4 ; 11)$ and one was positive for $\mathrm{t}(9 ; 22)$-p190 translocation. In the AML cohort, 21 patients were pediatric and 18 were adult. Median WBC was 100.000 mcL. Seven patients were positive for $t(15 ; 17)$ translocation. The samples were taken at the time of diagnosis and the patients were treated according to BFM or GMALL protocols. Bone marrow samples were obtained at the time of diagnosis. The clinical features of acute leukemia patients are summarized in Table 1. B-ALL (FLEB14-4) and T-ALL (MOLT4, JURKAT and TALL-1) cell lines were also included to the study. Healthy bone

\begin{tabular}{|c|c|c|}
\hline & ALL $(n=79)$ & AML $(n=39)$ \\
\hline \multicolumn{3}{|l|}{ Age } \\
\hline Pediatric & 71 & 21 \\
\hline Median (Min-Max) & 12 (16 days- 18 years) & 5 (1-15 years) \\
\hline Adult & 8 & 18 \\
\hline Median (Min-Max) & 30.5 (21-72 years) & 37 (20-71 years) \\
\hline \multicolumn{3}{|l|}{ Sex } \\
\hline Male & 50 & 23 \\
\hline Female & 29 & 15 \\
\hline Median WBC & 42.300 & 100.000 \\
\hline (Min-Max) & $1060-600.000$ & $3700-50.000$ \\
\hline \multicolumn{3}{|l|}{ Translocation } \\
\hline $\mathrm{t}(12 ; 21)$ positive & 4 & 0 \\
\hline $\mathrm{t}(4 ; 11)$ positive & 3 & 0 \\
\hline t(9;22)-p190 positive & 1 & 0 \\
\hline$t(15 ; 17)$ & 0 & 7 \\
\hline
\end{tabular}




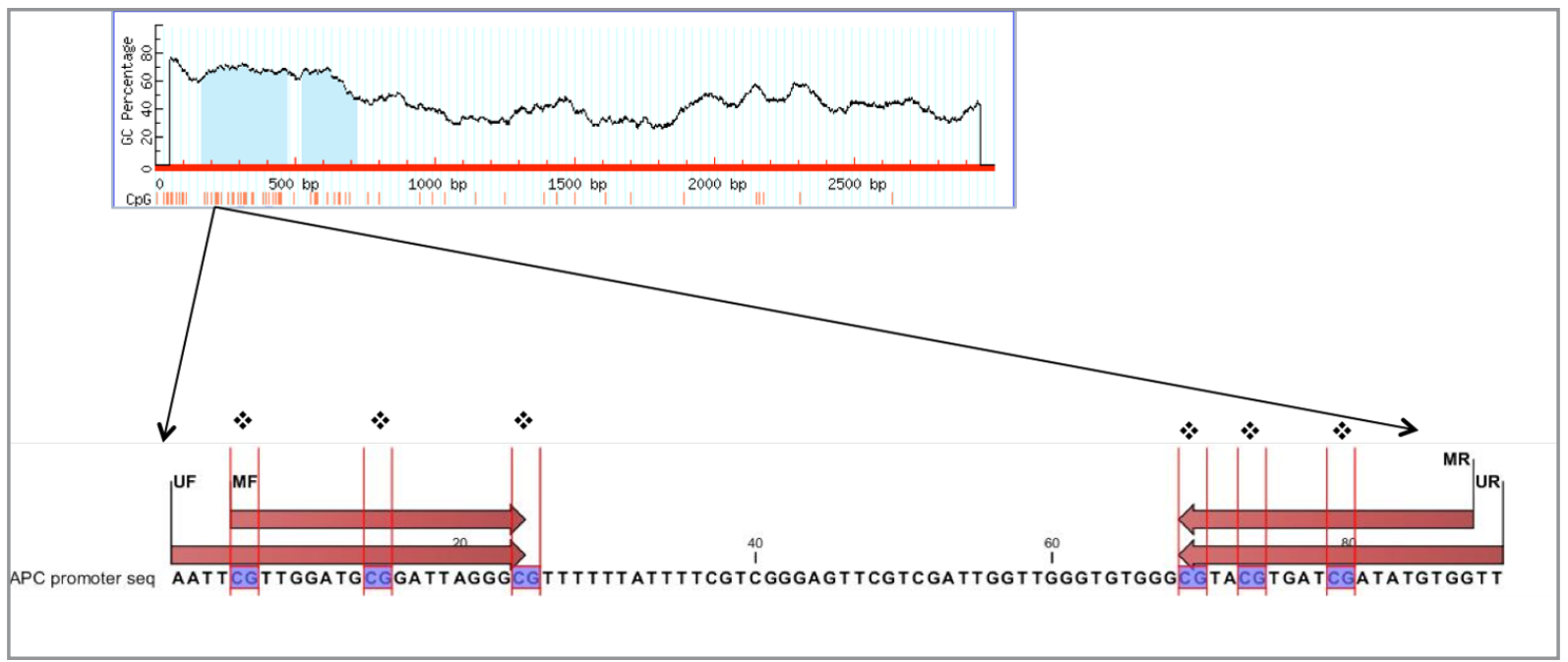

Figure 1. $\mathrm{CpG}$ island range (blue region) of APC gene as determined by Methprimer and methylation specific PCR primer sequences. Red fonts represent primer sequences, : represents CpG islands, MF: Methylated PCR Primer Forward, MR: Methylated PCR Primer Reverse, UF: Unmethylated PCR Primer Forward, UR: Unmethylated PCR Primer Reverse

marrow $(n=10)$ and total thymocytes sorted from healthy thymus tissue samples $(n=7)$ were used as control. The ethical committee of Istanbul Medical Faculty, Istanbul University approved this study and informed consents were obtained from all patients and healthy controls (reference number and date: 2008/305 and 20.02.2008).

\section{RNA Isolation and cDNA Synthesis}

Bone marrow samples were stored at $-800 \mathrm{C}$ after homogenization in the RTL buffer (Qiagen, $\mathrm{GmbH}$, Germany). Total RNA isolated by Qiagen RNeasy Protect Kit (Qiagen, GmbH, Germany). RNA samples were treated using DNAse $(1 \mathrm{U} / \mu \mathrm{g})$ to avoid possible DNA contamination resulting from isolation. RNA quality and quantity was checked with Nanodrop 1000 (Thermo Fisher Scientific, Germany) and cDNA was synthesized by random hexamers and MMLV reverse transcriptase (MBI Fermentase, Lithuia), from $1 \mu \mathrm{g}$ of total RNA according to manufacturer protocol (Roche Diagnostics, Mannheim, Germany).

\section{Bisulfite Treatment and Methylation Specific Polymerase Chain Reaction (MS-PCR)}

Genomic DNA was extracted from patients' bone marrow cells by using Qiagen DNA isolation kit
(Qiagen, GmbH, Germany). DNA quality and quantity was measured before $\mathrm{NaBiS}$ (sodium bisulphate) treatment that was described by Frommer et. al. ${ }^{14} \mathrm{NaBiS}$ treated DNA was purified by the Gene Clean III Kit (Q-Bio-gene) according to the manufacturer's instructions. After the bisulfite treatment, methylation specific polymerase chain reaction (MS-PCR) was used to amplify the promoter region of the APC gene in all samples.

MethPrimer (http://www.urogene.org/methprimer/ index1.html) program is used to determine the $\mathrm{CpG}$ island range of $A P C$ gene and to design the MS-PCR primers; APCMF:5'CGTTGGATGCGG ATTAGGGC,3',APCMR:5'CCTCATATCGATCA CGTACG3',MSPCRUF:5'AATTGGTTGGATGT GGATTAGGGT3',MSPCRUR:5'AACCTCATAT CAATCACATACA3' (Figure 1). A pooled DNA sample, obtained from 5 individuals, was treated with SssI methylase (New England Biolabs, United Kingdom) enzyme to obtain in vitro methylated (IVM) positive control in each run. MS-PCR results were evaluated on $3 \%$ agarose gel electrophoresis.

\section{Analysis of Gene Expression by Real Time Quantitative RT-PCR (QRT-PCR)}

Quantitative PCR (QRT-PCR) was carried out on the Light Cycler Instrument 480 (Roche Diagnos- 


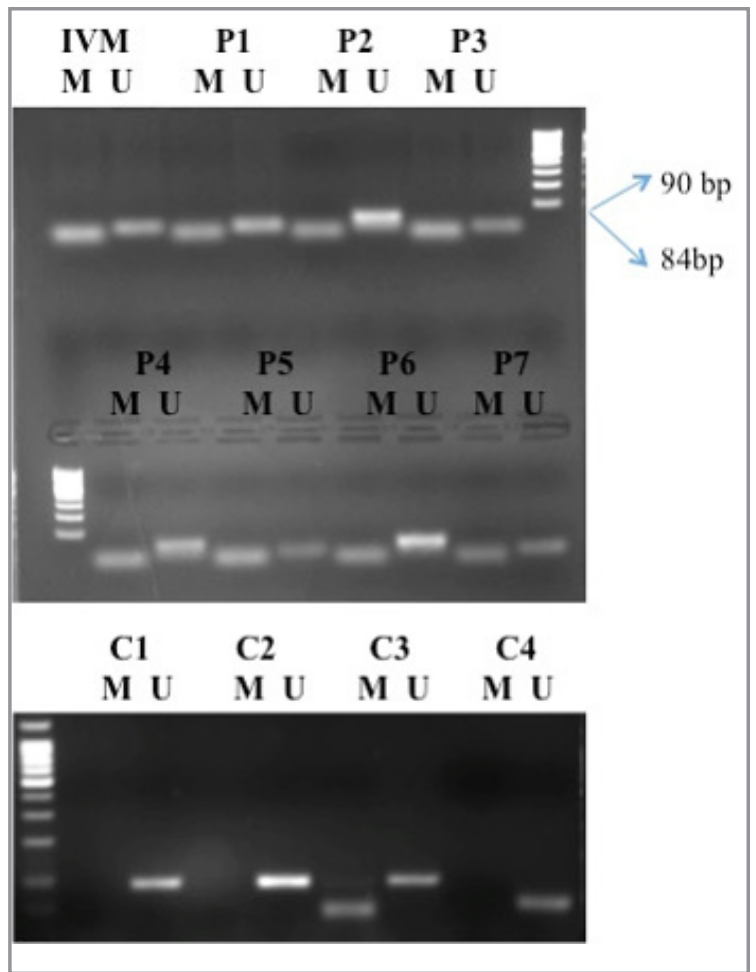

Figure 2. Methylation specific PCR in seven representative acute leukemias patients and four controls on 3\% agarose gel electrophoresis stained by EtBr. M; methylated (84bp), U: unmethylated (90bp) P; Patient, C; Contols, IVM; in vitro methylated sample.

tics, Mannheim, Germany), with the LightCyler 480 Fast Start SYBR Green I Master Kit (Roche Diagnostics, Manheim, Germany).

The PCR conditions were prepared according to the instructions of the manufacturer's protocol. 5 pmol of primers and $200 \mathrm{ng}$ of cDNA were used in each run and each sample was studied in duplicate. QRT-PCR primer sequences were; Forward: 5'GAGACAGATGGAGGTGCTGC3'Reverse: 5'GTAAGATGATTGGAATTATCTTCT3'. The specificity of product amplification was confirmed by melting curve analyses and agarose gel electrophoresis. The expression levels of APC were detected by quantitative-real time PCR. The 3 reference genes ( $\beta$-ACTIN, CYPA and ABL) were studied for normalization as described by Vandesompele et. al. ${ }^{15}$

\begin{tabular}{|lll|}
\hline \multicolumn{3}{|l|}{$\begin{array}{l}\text { Table 2. Clinical characteristics and the methylation status of } \\
118 \text { acute leukemia patients }\end{array}$} \\
\hline & $\begin{array}{l}\text { Methylated } \\
\mathbf{n}(\%)\end{array}$ & $\begin{array}{l}\text { Unmethylated } \\
\mathbf{n}(\%)\end{array}$ \\
\hline B-ALL $(n=63)$ & $31(49.2)$ & $32(50.8)$ \\
T-ALL $(n=16)$ & $10(62.5)$ & $6(37.5)$ \\
AML $(n=39)$ & $25(64.1)$ & $14(35.9)$ \\
Total $(n=118)$ & $66(56)$ & $52(44)$ \\
\hline
\end{tabular}

\section{Statistical Analysis}

Relative expression values were calculated according to the mathematic model based on the crossing points. ${ }^{16}$ Differences between the relative expression levels of cases and controls tested with MannWhitney $\mathrm{U}$ test. The correlation between methylation status and clinical parameters (sex, age, WBC count at diagnosis etc.) was examined. The Kaplan Mayer method was used to estimate the survival rates. Log rank test was used for survival analyses. $\mathrm{P}$ value of 0.05 or less (two-sided) was considered statistically significance. All statistical analyses were done by SPSS 10.0 software.

\section{RESULTS}

APC gene promoter methylation is detected in acute leukemia patients. To observe the methylation patterns of the 5' promoter region of the APC gene, we analyzed 79 ALL (T and B ALL), 39 AML primary patient samples (Figure 2). In total $56 \%$ of acute leukemia patients showed APC promoter methylation. Among the acute leukemia patient, $49.2 \%$ of B-ALL, $62.5 \%$ of T-ALL and $64.1 \%$ of AML samples were hypermethylated (Table 2). Also TALL-1 and FLEB14-4 cell lines were positive for methylation. In contrast, none of our control samples demonstrated APC promoter methylation.

\section{APC Expression in Acute Leukemia Patients (AL)}

To examine if the promoter methylation effects the expression of the $A P C$ gene, mRNA levels were also studied in AL patients. All of the acute lymph- 


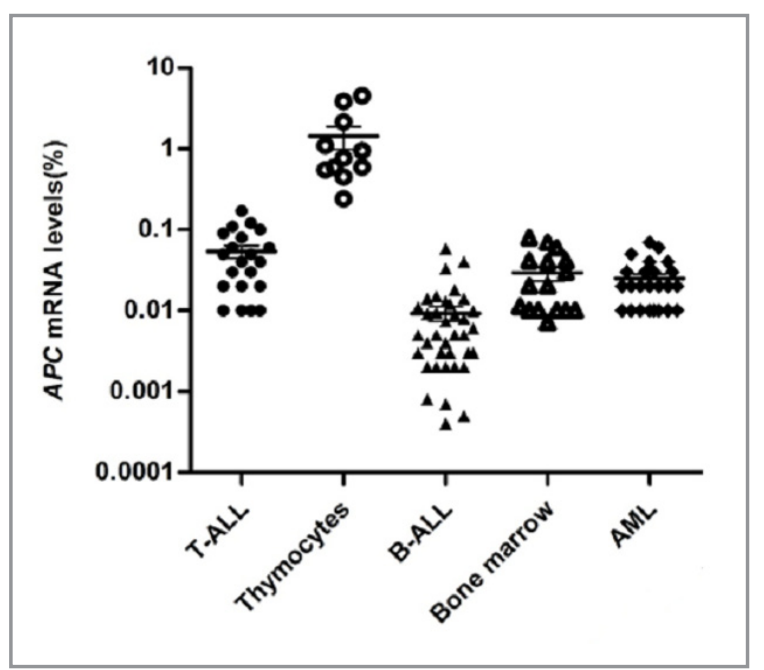

Figure 3. APC mRNA levels in acute leukemia samples and related controls. The APC mRNA levels were normalized by the mean value of 3 house keeping genes (Beta-actin, cyclophilin and $\mathrm{ABL})$

oblastic leukemia subgroups showed decreased mRNA levels compared to healthy controls. The decrease level in T-ALL and B-ALL patients were statistically significant $(\mathrm{p}<0.0001$ and $\mathrm{p}=0.001$, respectively) (Figure 3). Although the AML patients showed lower $A P C$ expression levels than control bone marrow samples the difference was not statistically significant $(\mathrm{p}=0.46$ ) (Figure 3 ).

There was no correlation between promoter methylation status of $A P C$ gene and clinical parameters (age, sex, WBC count, translocation status, etc.) of the samples. $A P C$ gene methylation $(\mathrm{p}=0.83)$ or mRNA expression levels $(\mathrm{p}=0.56)$ did not show a direct effect on overall survival (Figure 4).

\section{DISCUSSION}

As a negative regulator, $A P C$ gene has an important role in WNT pathway. Inactivation of $A P C$ gene may cause abnormal and constitutive activation of WNT signaling pathway. There are two possible mechanisms in silencing of $A P C$, gene mutations or promoter hypermethylation. $A P C$ gene mutations are highly frequent in colon cancer or hepatocellular carcinoma patients. ${ }^{17,18}$ In our previous study, we have examined the mutations in B-CATENIN and its destruction complex members, including $A P C$ gene, in acute leukemia patients and found that ligand independent activation of WNT due to APC mutations is not a common event in acute leukemia like in solid tumors. ${ }^{13}$ On the other hand, aberrant methylation in promoter region is known as an alternate mechanism for transcriptional silencing. Recent studies clearly showed epigenetic mechanisms have a prominent role in cancer. ${ }^{12}$ The promoter methylation of WNT pathway components was shown in several cancer types. ${ }^{19-24}$

$A P C$ promoter methylation was found in gastric cancers and also $48 \%$ of the adult T-ALL patients. ${ }^{23,25}$ Here we showed that $56 \%$ of acute leukemia patients have the promoter methylation of $A P C$
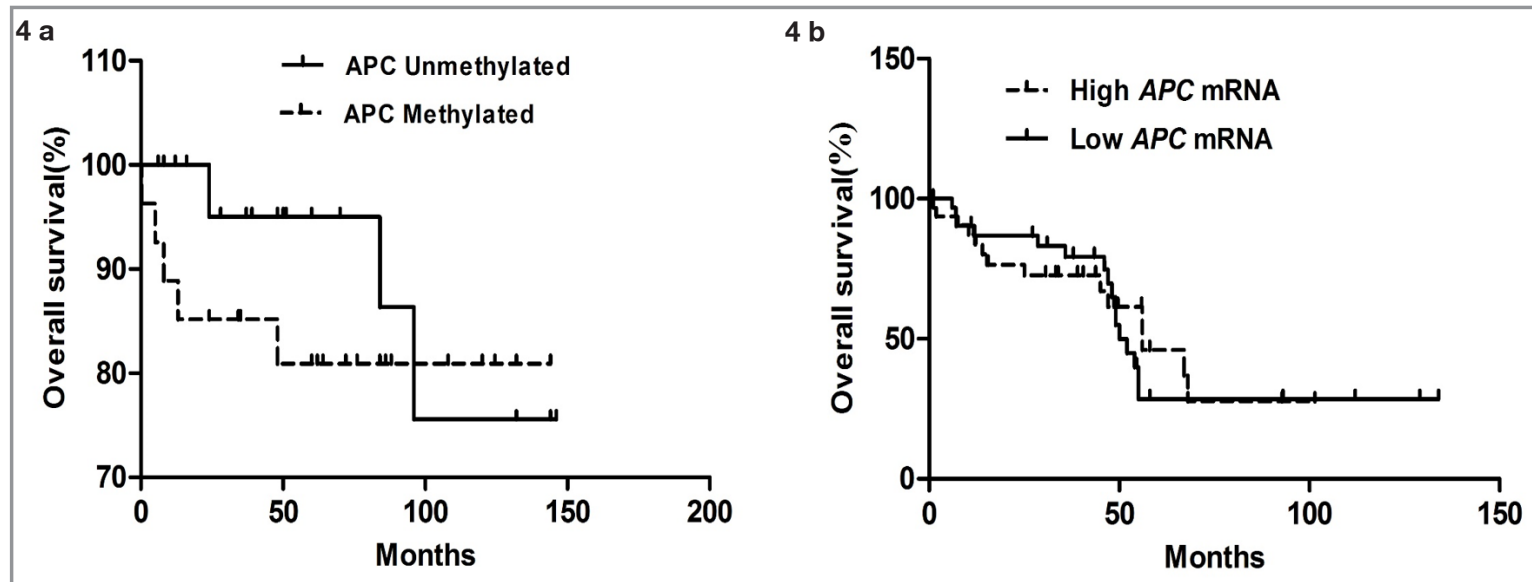

Figure 4. Overall Survival (OS) analysis in acute leukemia patients according to their methylation (4a) and expression status (4b) 
gene and in line with the literature among these around $50 \%$ of the T-ALL patients were methylated. On the other hand, Yang et al. declared that they have found no $A P C$ methylation in B-ALL patients but here we detected $A P C$ methylation in almost $50 \%$ of the pediatric B-ALL patients as well. This discrepancy might be due to difference between the $\mathrm{CpG}$ islands region studied. It was previously shown that APC gene was highly methylated in breast cancer samples but not in AML patients. ${ }^{26} \mathrm{In}$ our study the methylation status of AML samples is lower than ALL samples and the expression difference was not significant than control.

Differential methylation of $A P C$ promoter occurs among patient subgroups and cell lines, but not in healthy individuals, suggesting that hypermethylation of promoter $\mathrm{CpG}$ islands of the $A P C$ gene is a tumor-specific change in acute lymphoblastic leukemia.

In addition to gene deletions or mutations, methylation at $\mathrm{CpG}$ sites in the promoter region is an alternative pathway for gene inactivation. QRT-PCR results showed significantly lower $A P C$ mRNA levels in B and T cell leukemias and mostly in immature group. Our observation implicated that the methylation of the $A P C$ gene is associated with transcriptional silencing in ALL. The hypermethylation of $A P C$ gene is the main event that causes the low APC mRNA level in acute lymphoblastic leukemia and the epigenetic changes in WNT negative regulators can contribute to the leukemogenesis by untimely activation of WNT pathway.

\section{Acknowledgement:}

Authors would like to thank to Dr. Tiraje Celkan, Dr. Zeynep Karakaş and Dr. Gönül Aydoğan for the patient material. This work was supported by the Scientific and Technical Research Council of Turkey Grant Project no: $106 S 112$ and T.R. Prime Ministry State Planning Organization Grant Project no: 2005K120430.

\section{REFERENCES}

1. Pardal R, Clarke MF, Morrison SJ. Applying the principles of stem-cell biology to cancer. Nat Rev Cancer 12: 895-902, 2003.

2. Tiemessen MM, Staal FJ. Wht signaling in leukemias and myeloma: T-cell factors are in control. Future Oncol 11: 1757 1772, 2013.

3. Moore MA. Converging pathways in leukemogenesis and stem cell self-renewal. Exp Hematol 7: 719-737, 2005.

4. Gandhirajan RK, Poll-Wolbeck SJ, Gehrke I, Kreuzer KA. Wnt/ beta-catenin/LEF-1 signaling in chronic lymphocytic leukemia (CLL): a target for current and potential therapeutic options. Curr Cancer Drug Targets10 : 716-727, 2010.

5. $\mathrm{Ng} \mathrm{OH}$, Erbilgin $\mathrm{Y}$, Firtina S, et al. Deregulated WNT signaling in childhood T-cell acute lymphoblastic leukemia. Blood Cancer J 4: e192, 2014.

6. McCartney BM, Nathke IS. Cell regulation by the Apc protein Apc as master regulator of epithelia. Curr Opin Cell Biol 20 : 186-193, 2008.

7. Luu HH, Zhang R, Haydon RC, et al. Wnt/beta-catenin signaling pathway as a novel cancer drug target. Curr Cancer Drug Targets 4: 653-671, 2004.

8. Voorham QJ, Janssen J, Tijssen M, et al. Promoter methylation of Wnt-antagonists in polypoid and nonpolypoid colorectal adenomas. BMC Cancer 13: 603, 2013.

9. Chen Y, Li J, Yu X, et al. APC gene hypermethylation and prostate cancer: a systematic review and meta-analysis. Eur J Hum Genet 21: 929-935, 2013.

10. Klarmann GJ, Decker A, Farrar WL. Epigenetic gene silencing in the Wnt pathway in breast cancer. Epigenetics 3: 59-63, 2008.

11. Chim CS, Pang R, Fung TK, et al. Epigenetic dysregulation of Wnt signaling pathway in multiple myeloma. Leukemia 21: 2527-2536, 2007.

12. Esteller M, Herman JG. Cancer as an epigenetic disease: DNA methylation and chromatin alterations in human tumours. $J$ Pathol 196: 1-7, 2002.

13. Erbilgin $\mathrm{Y}, \mathrm{Ng} \mathrm{OH}$, Mavi $\mathrm{N}$, et al. Genetic alterations in members of the Wnt pathway in acute leukemia. Leuk Lymphoma 53: 508-510, 2012.

14. Frommer M, McDonald LE, Millar DS, et al. A genomic sequencing protocol that yields a positive display of 5-methylcytosine residues in individual DNA strands. Proc Natl Acad Sci U S A 89: 1827-1831, 1992.

15. Vandesompele J, De Preter K, Pattyn F, et al. Accurate normalization of real-time quantitative RT-PCR data by geometric averaging of multiple internal control genes. Genome Biol 7: RESEARCH0034, 2002. 
16. Livak KJ, Schmittgen TD. Analysis of relative gene expression data using real-time quantitative PCR and the 2(-Delta Delta C(T)) Method. Methods 25: 402-408, 2001.

17. Miyaki M, lijima T, Kimura J, et al. Frequent mutation of betacatenin and APC genes in primary colorectal tumors from patients with hereditary nonpolyposis colorectal cancer. Cancer Res 59: 4506-4509, 1999.

18. Sasikumar R, Rejitha JR, Binumon PK, Manoj M. Role of heterozygous APC mutation in niche succession and initiation of colorectal cancer--a computational study. PLoS One 6: e22720, 2011.

19. Grote HJ, Schmiemann V, Kiel S, et al. Aberrant methylation of the adenomatous polyposis coli promoter $1 \mathrm{~A}$ in bronchial aspirates from patients with suspected lung cancer. Int J Cancer 110: 751-755, 2004.

20. Dong SM, Kim HS, Rha SH, Sidransky D. Promoter hypermethylation of multiple genes in carcinoma of the uterine cervix. Clin Cancer Res 7: 1982-1986, 2001.

21. Esteller M, Corn PG, Baylin SB, Herman JG. A gene hypermethylation profile of human cancer. Cancer Res 61: 32253229, 2001.

22. Kawakami K, Brabender J, Lord RV, et al. Hypermethylated APC DNA in plasma and prognosis of patients with esophageal adenocarcinoma. J Natl Cancer Inst 92: 1805-1811, 2000.

23. Yang $\mathrm{Y}$, Takeuchi S, Tsukasaki K, et al. Methylation analysis of the adenomatous polyposis coli (APC) gene in adult T-cell leukemia/lymphoma. Leuk Res 29: 47-51, 2005.

24. Hatirnaz Ng Ö, Firtina S, Can I, et al. A possible role for WNT5A hypermethylation in Pediatric Acute Lymphoblastic Leukemia. Turkish Journal of Hematology 32: 127-135, 2015.

25. Tsuchiya T, Tamura G, Sato K, et al. Distinct methylation patterns of two APC gene promoters in normal and cancerous gastric epithelia. Oncogene 19: 3642-3646, 2000.

26. Griffiths EA, Gore SD, Hooker C, et al. Acute myeloid leukemia is characterized by Wnt pathway inhibitor promoter hypermethylation. Leuk Lymphoma 51: 1711-1719, 2010.

\section{Correspondence:}

Dr. Muge SAYITOGLU

Istanbul Üniversitesi

Deneysel Tip Arastirmalari Enstitüsü,

Genetik Bölümü

Vakif Gureba Caddesi

34093, Fatih, ISTANBUL / TURKEY

Tel: (+90-212) 4142000 / 33312

Fax: (+90-212) 6357757

e-mail: mugeay@istanbul.edu.tr 